\title{
Non-enzymatic Browning during Thermal Processing of Canned Sardine
}

\author{
Munehiko TANAKA* and Takeshi TAGUCHI* \\ (Accepted December 12, 1984)
}

\begin{abstract}
The rate of non-enzymatic browning reaction taken place during thermal processing of canned. sardine was determined. Losses of glucose and G6P in the meat and liquid portions of canned sardine during thermal processing were found to follow first-order kinetics. The loss rate of G6P was greater than that of glucose. Losses of glucose and G6P in meats were larger than those in liquids. However, the activation energies for these losses were approximately $20 \mathrm{kcal} / \mathrm{mol}$ for both meat and liquid portions. The available lysine degraded at a slightly slower rate, but its activation energy was also equivalent to those for glucose and G6P losses. The development of brown color in liquids of canned sardine increased with the increase in processing time by a first-order reaction (activation energy $=18.8 \mathrm{kcal} / \mathrm{mol}$ ). On the other hand, browning was not visually detected in the meat portion. It was found that canned sardine meats softened with the processing time at every temperature employed in this study (activation energy $=35.0 \mathrm{kcal} / \mathrm{mol}$ ).
\end{abstract}

In the previous papers, ${ }^{1-3)}$ it has been reported that glucose content of sardine meats increased gradually during ice storage and its loss due to non-enzymatic browning reaction during the sterilization process was related to the deteriorative changes in quality of canned sardine. In general, non-enzymatic browning reaction, which occurs during thermal processing, leads to the loss of quality such as the reduction of nutritional value of proteins, development of bitter taste and undesirable flavors, and the formation of browning pigments. To elucidate the mechanism of quality loss during thermal processing of canned sardine, it is necessary to investigate the effect of heating temperature on the browning reaction.

In the present paper, various kinetic parameters concerning non-enzymatic browning reaction in the meat and liquid portions of canned sardine were determined and compared.

\section{Materials and Methods}

\section{Pretreatment of Sardines}

Sardines Sardinops melanosticta (average body weight: $115 \mathrm{~g}$, average body length: $24 \mathrm{~cm}$ ) were used. Heads and viscera of sardines were removed and then soaked in ice-cold $10 \%$ salt solution for $20 \mathrm{~min}$. After soaking, sardines were dressed (fins and spinal bones removed) and minced by a meat chopper. Two hundred and ten grams of minced sardine meats were filled into a lacquered
No. 6 can (diameter: $74.1 \mathrm{~mm}$, height: $59.0 \mathrm{~mm}$ ) and the cans were vacuum-seamed.

\section{Thermal Processing}

After closed, cans were placed in tap water to adjust the initial temperature at $16^{\circ} \mathrm{C}$, they were heated in a vertical still retort at temperatures as described below:

$110^{\circ} \mathrm{C} ; 50,80,110,150 \mathrm{~min}$

$115^{\circ} \mathrm{C} ; 35,50,70,90 \mathrm{~min}$

$120^{\circ} \mathrm{C} ; 30,40,50,62 \mathrm{~min}$

$125^{\circ} \mathrm{C} ; 25,35,42,48 \mathrm{~min}$

Two cans in each thermal processing were fitted with thermocouples monitoring the central temperature. Heat penetration rate at the center of a can and retort temperature were measured by a Type 29-CTF recorder (Electro-laboratoriet, Copenhagen, Denmark). After each thermal processing, heated cans were immediately cooled in ice-cold water and stored at $4^{\circ} \mathrm{C}$.

\section{Analytical Procedures}

Six cans from each thermal processing were opened. The meat and liquid portion (simply called liquid hereafter) were separated and analyzed individually. The liquid was filtered through a No. 2 filter paper for analyses.

For the determination of glucose and glucose-6phosphate (G6P) in meats, the samples were extracted with $6 \%$ perchloric acid (PCA) according to the procedure of TARR. ${ }^{4)}$ Free glucose in PCA extracts (neutralized with $20 \% \mathrm{KOH}$ solution)

* Department of Food Technology and Engineering, Tokyo University of Fisheries, Konan 4-5-7, Minato, Tokyo 108, Japan (田中宗彦・田口 武: 東京水産大学食品工学科). 
and in the liquids was determined by the Glucostat reagent (Worthington Chemical Corp.), which is specific to $\beta$-D-glucose. Free G6P was enzymatically assayed according to the method of HoнORst. ${ }^{5)}$ Available lysine of canned sardine meats was determined by 2,4,6-trinitrobenzenesulfonic acid (TNBS) method. ${ }^{6}$ )

Development of brown color in sardine meats during thermal processing was monitored by a digital color and color difference meter Type 1010 (Nippon Denshoku Kogyo Co. Ltd.). The extent of browning of the liquids was measured as the absorbance at $420 \mathrm{~nm}$ by a Hitachi spectrophotometer Model 200-20. The hardness of canned sardine meats was determined by a rheometer Type R-UDJ (San Kagaku Co. Ltd.) with a plunger diameter $0.5 \mathrm{~cm}$.

\section{Results and Discussion}

\section{Meat Portion}

Typical heat penetration curve of canned sardine is shown in Fig. 1. For the analysis of heat penetration into canned foods, two values $j$ and $f$ are usually taken into consideration. A factor which locates the intersection of the extension of the straight-line portion of the heat penetration curve and a vertical line representing beginning of process is referred to as the $j$ value. The $j$ values, also called as the heating lag factor, were

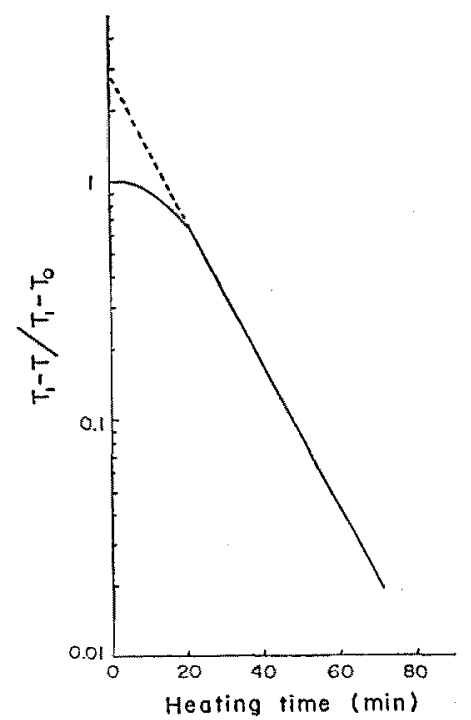

Fig. 1. Typical heating curve of canned sardine.

$T_{1}$ : Retort temperature, $T$ : Can temperature, $T_{0}$ : Initial temperature.
2.70 at $110^{\circ} \mathrm{C}$ heating, 2.78 at $115^{\circ} \mathrm{C}, 2.82$ at $120^{\circ} \mathrm{C}$ and 2.88 at $125^{\circ} \mathrm{C}$, showing a slight increase with increasing processing temperature. This is because this value is mainly influenced by the comeup time. On the other hand, the $f$ value is defined as the time, in minute, required for the straight-line portion of the heat penetration curve to transverse one log cycle, that is, the slope of the curve. The $f$ value was about $32 \mathrm{~min}$ irrespective of the processing temperature, since the variety of food packed in cans and the size of cans only affect this value.

Rates of non-enzymatic browning reaction taken place in canned sardine meats during thermal processing were estimated. Although sardine meats contain a variety of reducing sugars, amounts of glucose and G6P were determined. Only available lysine was measured as a representative of amino compounds, because its loss due to the browning reaction is well-correlated to a lowering of nutritional value of proteins. ${ }^{8,8)}$

Fig. 2 presents changes of glucose content in canned sardine meats during thermal processing. Loss of glucose was found to follow a first-order reaction for all four temperatures $(110,115,120$, $125^{\circ} \mathrm{C}$ ). The slope for the semi-logarithmic curve was used to estimate the reaction rate constant (k) for the loss of glucose. Rate constants $\left(\mathrm{min}^{-1}\right)$ were 0.0092 at $110^{\circ} \mathrm{C}, 0.0129$ at $115^{\circ} \mathrm{C}, 0.0164$ at $120^{\circ} \mathrm{C}$ and 0.0251 at $125^{\circ} \mathrm{C}$. An activation energy for this reaction was obtained from the slope of an

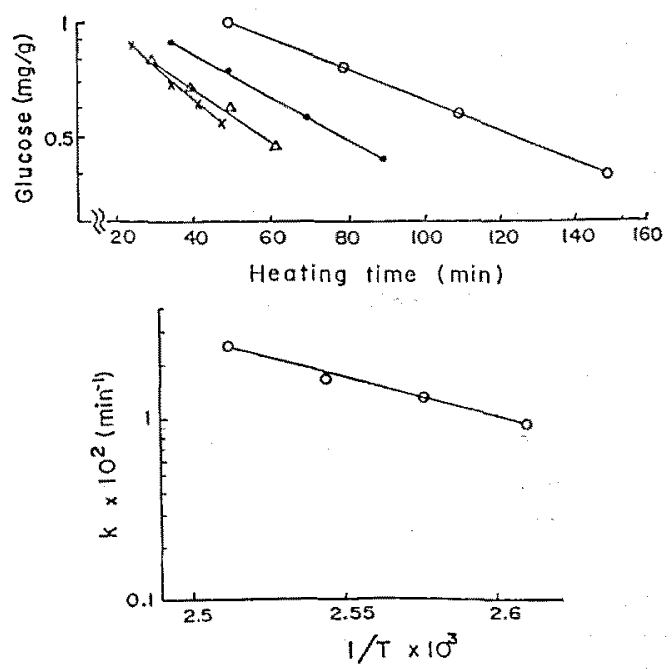

Fig. 2. Loss of glucose in canned sardine meats during thermal processing and an ArRHENIUs plot. O: $110^{\circ} \mathrm{C}, 0: 115^{\circ} \mathrm{C}, \Delta: 120^{\circ} \mathrm{C}, \times: 125^{\circ} \mathrm{C}$. 


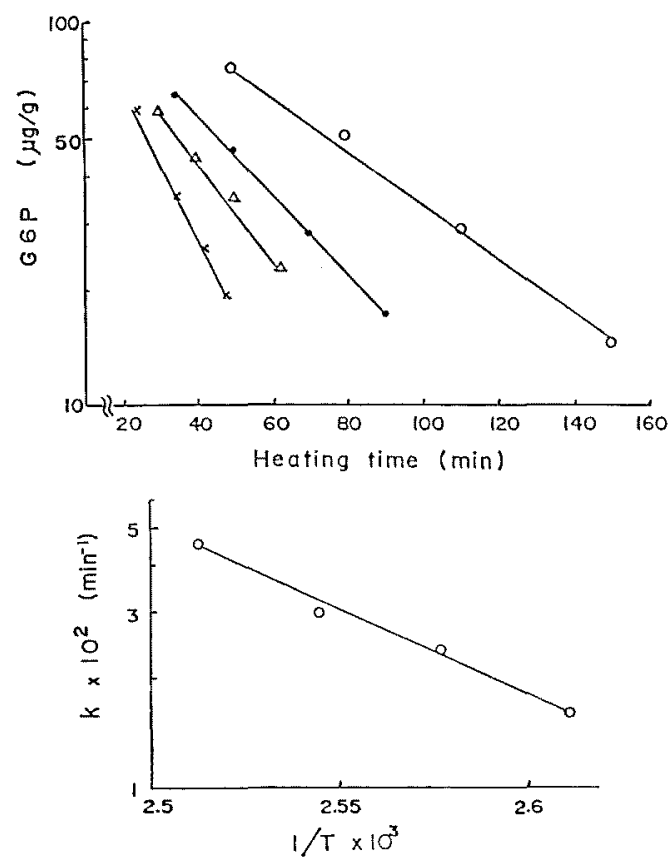

Fig. 3. Decrease of $\mathrm{G} 6 \mathrm{P}$ in canned sardine meats during thermal processing and an ARRHENIUs plot. $\mathrm{O}: 110^{\circ} \mathrm{C}, \bullet: 115^{\circ} \mathrm{C}, \triangle: 120^{\circ} \mathrm{C}, \times: 125^{\circ} \mathrm{C}$.

ArrhenIUS plot $(\log \mathrm{k}$ vs. 1/T, Fig. 2). The activation energy for the loss of glucose in canned sardine during heat processing was thus calculated as $20.4 \mathrm{kcal} / \mathrm{mol}$.

Losses of G6P in canned sardine meats during thermal processing are given in Fig. 3. As was observed in loss of glucose, the loss reaction of G6P was also first-order. For temperatures of $110,115,120$ and $125^{\circ} \mathrm{C}$, the rate constants for loss of G6P were $0.0161,0.0238,0.0297$ and 0.0454 , respectively. The rate constants were about double those for loss of glucose at the respective temperatures, indicating that G6P in sardine meats degrades at a faster rate than does glucose. However, the contribution of glucose to the nonenzymatic browning toward sardine meats during thermal processing may be more important compared with that of G6P, because the glucose content in sardine meats was approximately 10 times larger than the G6P content. The rate constants for loss of G6P in an ARRHENIUS plot yielded an activation energy of $21.0 \mathrm{kcal} / \mathrm{mol}$, which was comparable to that for loss of glucose.

Since the initial stage of the non-enzymatic browning reaction is the combination between a reducing sugar and an amino compound, loss rate of available lysine was chosen to be determined in
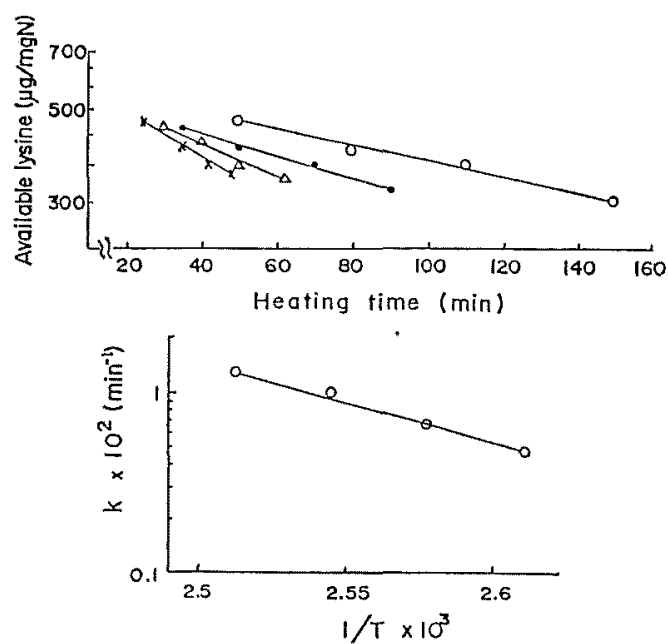

Fig. 4. Loss of available lysine in canned sardine meats during thermal processing and an ARRHENIUS plot.

$\mathrm{O}: 110^{\circ} \mathrm{C}, \quad: 115^{\circ} \mathrm{C}, \triangle: 120^{\circ} \mathrm{C}, \times: 125^{\circ} \mathrm{C}$.
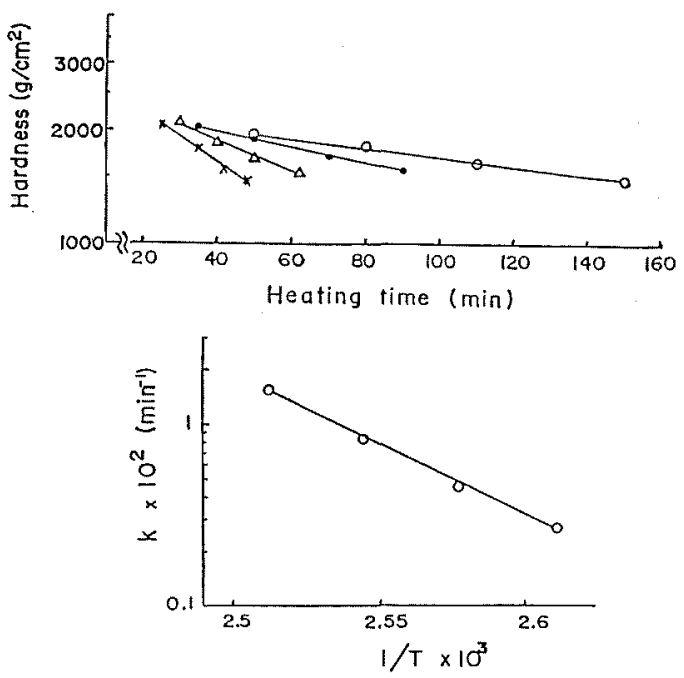

Fig. 5. Decrease in hardness of sardine meats during thermal processing and an ARRHENIUS plot.

$O: 110^{\circ} \mathrm{C}, \bullet: 115^{\circ} \mathrm{C}, \triangle: 120^{\circ} \mathrm{C}, \times: 125^{\circ} \mathrm{C}$.

this study (Fig. 4). As can be seen from Fig. 4, the data exhibit first-order kinetics. The rate constants $\left(\mathrm{min}^{-1}\right)$ were $0.0048\left(110^{\circ} \mathrm{C}\right), 0.0069\left(115^{\circ} \mathrm{C}\right)$, $0.0099\left(120^{\circ} \mathrm{C}\right)$, and $0.0129\left(125^{\circ} \mathrm{C}\right)$. Those values were fairly smaller than those for losses of glucose and G6P. The activation energy was $19.8 \mathrm{kcal} /$ mol. The activation energies for losses of glucose, G6P, and available lysine are in the range expected for the non-enzymatic browning reaction as reviewed by WARMBIER et $a l{ }^{10}{ }^{10}$ 
Aside from the browning reaction, changes in texture (hardness) of canned sardine meats during thermal processing were also examined. It was apparent from Fig. 5 that sardine meats became softened with the processing time at every processing temperature used in this study. The softening reaction appeared to exhibit first-order kinetics, having the rate constant $\left(\mathrm{min}^{-1}\right)$ of 0.0027 $\left(110^{\circ} \mathrm{C}\right), 0.0046\left(115^{\circ} \mathrm{C}\right), 0.0085\left(120^{\circ} \mathrm{C}\right)$, and $0.0154\left(125^{\circ} \mathrm{C}\right)$. The calculated activation energy for texture softening was $35.0 \mathrm{kcal} / \mathrm{mol}$. The physical significance of this activation energy is obscure, because it is a description of the summed effect of various chemical reactions including the denaturation of proteins. The additional study under different thermal processing conditions will be necessary to characterize the softening of canned sardine meats.

\section{Liquid Portion}

The extent of browning in liquids of canned sardine during thermal processing was measured as the absorbance at $420 \mathrm{~nm}$. The results are depicted in Fig. 6. It is obvious that brown color in liquids developed with increasing temperature under thermal processing conditions employed in this study. At the temperatures of 110,115 , 120 , and $125^{\circ} \mathrm{C}$, the rate constants $\left(\mathrm{min}^{-1}\right)$ were $0.0062,0.0083,0.0128$, and 0.0156 , respectively, and the computed activation energy was 18.8 $\mathrm{kcal} / \mathrm{mol}$. The color of canned sardine meats
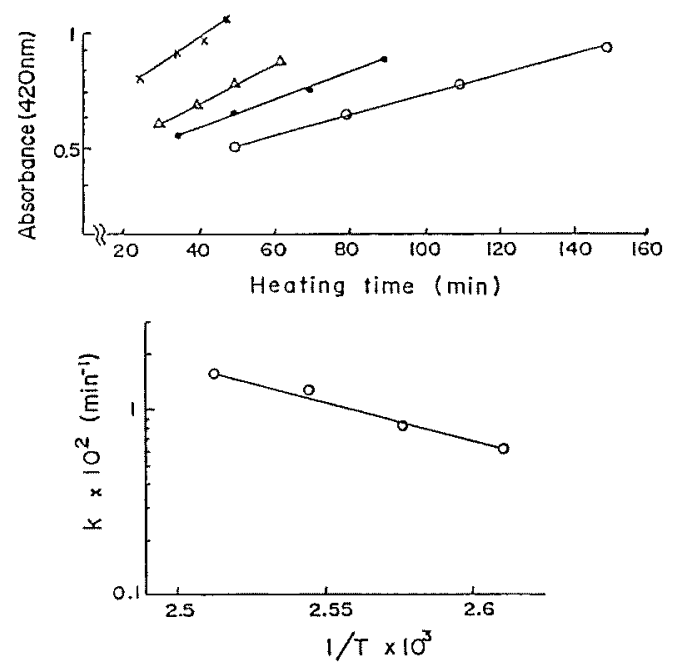

Fig. 6. Increase in absorbance (at $420 \mathrm{~nm}$ ) of liquids from canned sardine during thermal processing and an ARrhenius plot.

$$
\text { O: } 110^{\circ} \mathrm{C}, \bullet: 115^{\circ} \mathrm{C}, \triangle: 120^{\circ} \mathrm{C}, \times: 125^{\circ} \mathrm{C} \text {. }
$$

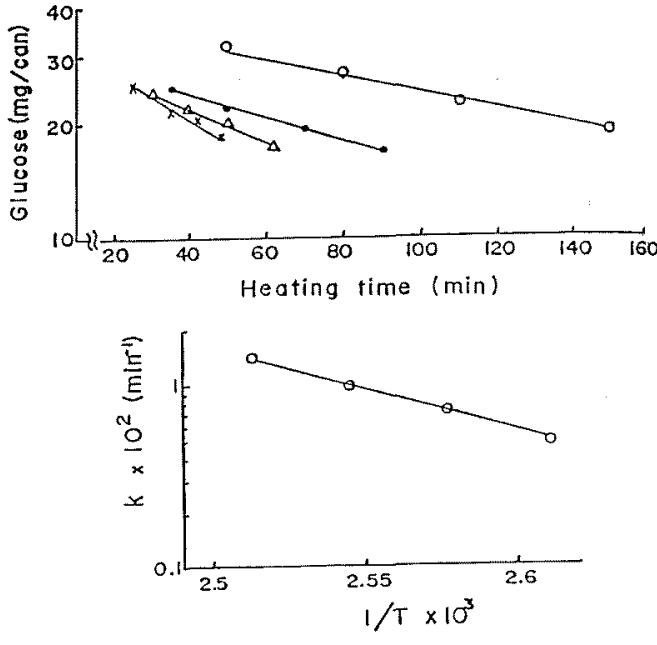

Fig. 7. Loss of glucose in liquids from canned sardine during thermal processing and an ARRHENIUs plot. $\mathrm{O}: 110^{\circ} \mathrm{C}, \bullet: 115^{\circ} \mathrm{C}, \triangle: 120^{\circ} \mathrm{C} \times: 125^{\circ} \mathrm{C}$.
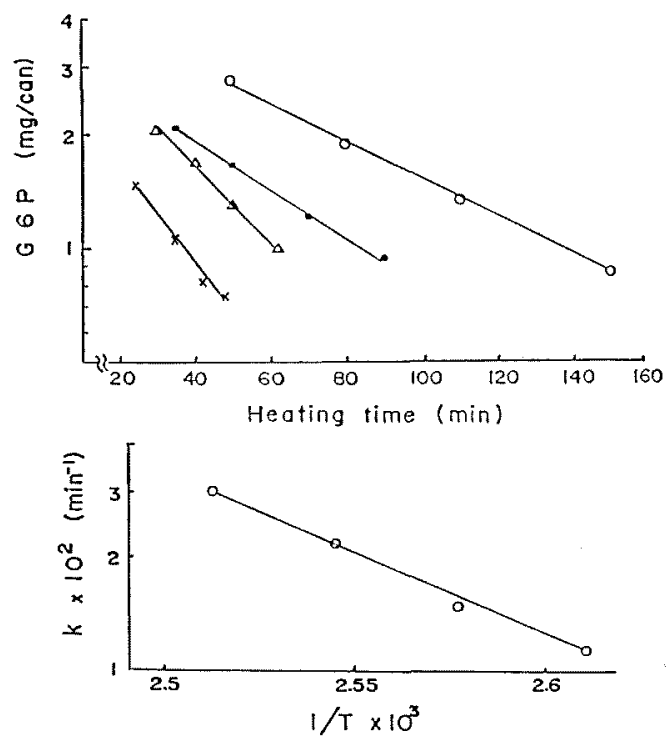

Fig. 8. Decrease of $\mathrm{G} 6 \mathrm{P}$ in liquids from canned sardine during thermal processing and an ARRHENIUS plot.

$$
\mathrm{O}: 110^{\circ} \mathrm{C}, \bullet: 115^{\circ} \mathrm{C}, \Delta: 120^{\circ} \mathrm{C}, \times: 125^{\circ} \mathrm{C} \text {. }
$$

was also determined by a color-color difference meter. Since the water activity of meats is smaller than that of liquids, the browning reaction should take place at a faster rate in meats. ${ }^{11)}$ However, the development of brown color in canned sardine meats was not detected. This may be because sardine meat itself has a dark brown color.

Contents of glucose and G6P in liquids were determined to estimate their loss rates. Since the 
amount of liquid in canned sardine was observed to increase with increasing processing time at every temperature, glucose and G6P contents were expressed as $\mathrm{mg} / \mathrm{can}$ (Figs. 7 and 8 ). As can be seen, both losses followed first-order kinetics. The rate constants were $0.0048\left(110^{\circ} \mathrm{C}\right), 0.0072$ $\left(115^{\circ} \mathrm{C}\right), 0.0099\left(120^{\circ} \mathrm{C}\right), 0.0142\left(125^{\circ} \mathrm{C}\right)$ for losses of glucose, and $0.0115\left(110^{\circ} \mathrm{C}\right), 0.0150\left(115^{\circ} \mathrm{C}\right)$, $0.0220\left(120^{\circ} \mathrm{C}\right), 0.0304\left(125^{\circ} \mathrm{C}\right)$ for losses of G6P. The activation energies for losses of glucose and G6P were 21.8 and $19.7 \mathrm{kcal} / \mathrm{mol}$, respectively. Those values were fairly comparable to those for losses of glucose and G6P in the canned meats. However, the degradation of glucose and G6P in liquids were slower than those in meats. This may be due to the difference of the water activity between them.

As a conclusion, the kinetic parameters obtained in this study will yield useful informations as to the sterilization and shelf life of the canned food with respect to the non-enzymatic browning reaction. Furthermore, it will be necessary to collect more data on other kinetic parameters concerning the loss of quality or nutritional value of canned foods such as the deterioration of lipids.

\section{References}

1) T. Taguchi, M. Tanaka, S. Okubo, and $K$. SuzukI: Bull. Japan. Soc. Sci. Fish., 48, 17651769 (1982).

2) M. TANaka, K. SuzukI, and T. Taguchi: Bull. Japan. Soc. Sci. Fish., 49, 1155 (1983).

3) M. Tanaka, K. Suzuki, and T. Taguchr: $J$. Tokyo Univ. Fish., 70, 9-15 (1983).

4) H. L. A. TARR: J. Fish. Res. Bd. Canada, 25, 1539-1554 (1968).

5) H.J. HoHorst: in "Methods of Enzymatic Analysis" (ed. by H. U. BergmeYer), Academic Press, New York, 1973, pp. 134-138.

6) M. L. KAKADE and I.E. LIENER: Analytical Biochem., 27, 273-280 (1969).

7) I. Shibazaki: Shin Shokuhin Sakkin Kohgaku, Kohrin, Tokyo, 1983, pp. 89-97.

8) K.J. Carpenter: Nutr. Abst. \& Reviews, 43, 424-451 (1973).

9) T. F. Tsao, A. L. Frey, and J. M. Harper: $J$. Food Sci., 43, 1106-1108 (1978).

10) H. D. WarmbieR, R. SCHNICKeLS, and T.P. LABUZA: J. Food Sci, 41, 981-983 (1976).

11) T.P. LABUZA: CRC Critical Rev. in Food Technol., September, 217-241 (1972). 